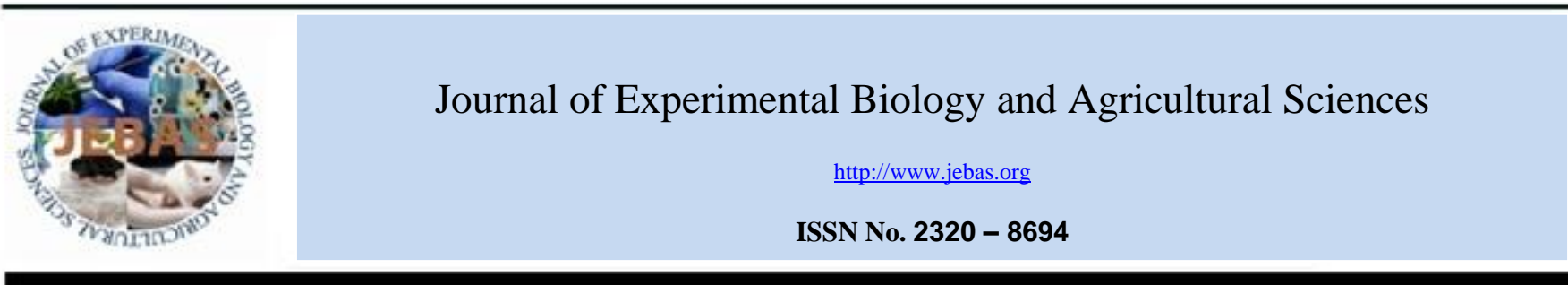

\title{
A NARRATIVE REVIEW ON MINDFULNESS PRACTICES IN OPTIMIZING PERFORMANCE AMONG SPORTS INDIVIDUALS
}

\section{Vinodhkumar Ramalingam ${ }^{1}$, Cheong Soon Keng ${ }^{2}$, Poh Foong Lee ${ }^{3 *}$}

${ }^{1}$ Faculty of Health and Life sciences, INTI International University, 71800 Nilai, Malaysia.

${ }^{2}$ Faculty of Medicine and Health Sciences, University Tunku Abdul Rahman, 43000 Kajang, Malaysia.

${ }^{3}$ Lee Kong Chian Faculty of Engineering and Science, University Tunku Abdul Rahman, 43000 Kajang, Malaysia.

Received - July 18, 2020; Revision - September 17, 2020; Accepted - January 03, 2021

Available Online - March 25, 2021

DOI: http://dx.doi.org/10.18006/2021.9(Spl-1-GCSGD_2020).S62.S70

\section{KEYWORDS \\ Athletes \\ Depression \\ Mindfulness \\ Sports anxiety \\ Sports performance}

\begin{abstract}
Mindfulness practice has become an increasingly popular intervention in optimizing athletic performance in sports. Numerous studies have reported on applying mindfulness for improving the performance of various sports such as tennis, table tennis, shooting, cricket, archery, golf, running, hockey, swimming, and cycling. This narrative review addresses different existing mindfulness programs that enhance sports performance, the outcome measures of mindfulness therapy, and identifies the anxiety and depression that affect the performance of sports individuals. To cope with the issues, the efficacy of mindfulness in performance enhancement and future research directions on mindfulness needs attention.
\end{abstract}

* Corresponding author

E-mail: leepf@utar.edu.my (Poh Foong Lee)

Peer review under responsibility of Journal of Experimental Biology and Agricultural Sciences.

Production and Hosting by Horizon Publisher India [HPI] (http://www.horizonpublisherindia.in/).

All rights reserved.
All the articles published by Journal of Experimental Biology and Agricultural Sciencesare licensed under a Creative Commons Attribution-NonCommercial 4.0 International License Based on a work at www.jebas.org.

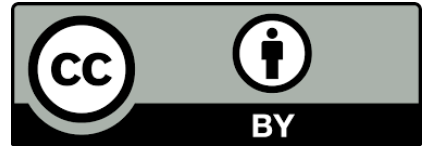




\section{Introduction}

The term mindfulness refers to the way that individuals pay attention to their own experiences from moment to moment with non-judgmental attitudes (Kabat-Zinn, 2009; Kabat-Zinn, 2012). Quite recently, considerable attention has been paid to mindfulness practice, it originated from Buddhist tradition where it developed through meditation and involves cultivating an ability to be nonreactive to thoughts, feelings, and body sensations (Mize, 2015). The mindfulness practice is an act of focusing or attention on being in the present moment, for instance by focusing completely on taking in its scent, warmth, taste, drinking a hot cup of tea, and removing overpowering emotions from the mind. The mindfulness model by Hölzel et al. (2011) specifies this underlying mechanism act as an active component in mindfulness practice where emotion regulation, perspective on the self, and attention regulation creates body awareness. According to Ludwig \& Kabat-Zinn (2008), the mindfulness concept comprises five major characteristics which include the experience of being present, awareness, acceptance, attention, and the transformative process of being mindful and moving towards a more integrated way of living. By considering these characteristics, towards individual sports achievements attention is one of the important factors, that stimulate the inner thoughts and emotions of an athlete through mindfulness (Lutkenhouse, 2007).

Therefore, the purpose of this review is to identify the different types of anxiety and depression, which affects individual sports performance and the effect of various mindfulness approaches that enhancing sports performance. And to find the outcomes measurement tools applied in mindfulness therapy. The sports enhancement mindfulness programs were originated from various mindfulness methods like Mindfulness-based stress reduction (MBSR), Mindfulness-based Cognitive therapy (MBCT), Mindfulness - acceptance commitment (MAC), Mindful sports performance enhancement (MSPE), and Mindfulness Meditation Training for sports (MMTS) as shown in Table 1.

Table 1Diverse approaches in Mindfulness

\begin{tabular}{|c|c|c|}
\hline Source & Mindfulness techniques & Duration of the intervention \\
\hline Kabat-Zinn, 1990 & $\begin{array}{l}\text { Mindfulness-based } \\
\text { (MBSR) }\end{array}$ & $\begin{array}{l}\text { Breathing and mindfulness techniques for } 90 \\
\text { minutes in a week for } 8 \text { weeks }\end{array}$ \\
\hline Segal et al., 2002 & $\begin{array}{l}\text { Mindfulness-based Cognitive therapy } \\
(\mathrm{MBCT})\end{array}$ & $\begin{array}{l}\text { Mindful attention, nonjudgmental acceptance } \\
\text { of internal states, and commitment to } \\
\text { achieving valued goals for } 2 \text { hours per week } \\
\text { for } 8 \text { weeks }\end{array}$ \\
\hline Gardner \& Moore, 2004 & $\begin{array}{l}\text { Mindfulness - acceptance commitment } \\
\text { (MAC) }\end{array}$ & $\begin{array}{l}\text { Seven weekly meeting or modules includes } \\
\text { in-session exercises and discussion on the } \\
\text { skills being learned }\end{array}$ \\
\hline Kaufman et al., 2009 & $\begin{array}{l}\text { Mindful sports performance enhancement } \\
\text { (MSPE) }\end{array}$ & $\begin{array}{l}\text { Mindfulness exercises, including walking } \\
\text { meditation, adapted to participants' sport of } \\
\text { focus weekly } 90 \text {-minute for } 4 \text { weeks }\end{array}$ \\
\hline Baltzell \& Akhtar, 2014 & $\begin{array}{l}\text { Mindfulness Meditation Training for } \\
\text { sports (MMTS) }\end{array}$ & $\begin{array}{l}6 \text { weeks program consisting of two sessions } \\
(30 \text { minutes }) \text { per week, and integrating } \\
\text { mindfulness training and traditional } \\
\text { psychology skills training (e.g., imagery and } \\
\text { self-talk) }\end{array}$ \\
\hline Pineau et al., 2014 & Expand version of MSPE & $\begin{array}{l}\text { Raisin exercise, the body scan, mindful } \\
\text { breathing, the sitting meditation, mindful } \\
\text { yoga, and the walking meditation } 6 \text { weeks } \\
\text { program consisting of weekly } 90 \text {-minutes } \\
\text { group sessions and daily home practice }\end{array}$ \\
\hline
\end{tabular}

Journal of Experimental Biology and Agricultural Sciences http://www.jebas.org 
Mindfulness practice prepares an individual's brain prefrontal cortex to be calm and prepare the mind to stay focused by avoiding distractive thoughts and perform at the best to reduce the stress response in the brain (Kabat-Zinn, 1990). On the other hand, a higher level of mindfulness practice activates the insular cortex of the brain and brings an individual's attention inward (Huang, 2016), which calms the participant's mind by lowering the stress hormone (resting cortisol levels) (Rosenkranz et al., 2013). Further, Dr. Kristen Race, founder of "Mindful Life" reported that the awareness and recognizing of the body movements enhanced the association between the body and mind (Yeh, 2016). This would in turn help in sensing the physiological responses, like muscle tension or short breathing patterns that make an individual respond immediately with a conscious mind by aware of what is going on both physically and mentally (Race, 2014). From Denny \& Steiner, (2009) findings among Stanford student-athletes $(\mathrm{N}=140)$ toward coping with performance hardship showed that internal factors like mindfulness, self-restraint, locus of control, and self-esteem were more potent, better account for happiness, and maintained throughout than the external factors (playing time, scholarship) that referring to the mindfulness model (Hölzel et al., 2011). These reports have shown that the mindfulness practice had brought more inner peace to calm the sports individuals.

\section{Psychological status of an athlete}

\subsection{Common psychological challenges and Mindfulness effects}

In sports, athletes generally engage with positive emotions like joy and happiness that brings in by their satisfying performance, whereas concurrently, they do experience negative emotions such as anger, distress, anxiety, over-arousal that may hurdle their way in performance. The right amount of good stress helps sports individuals to be prepare, focus, and perform their sports at an optimal level. Equally bad stress, distress may hinder athletes to accomplish a task. Besides, anxiety among sports individuals can be recognized in three levels, cognitive as a thought process, somatic as a physical response, and behavioral as patterns of behavior (Karageorghis \& Terry, 2010; Weinberg \& Gould, 2011). Additionally, a study by Elmagd (2016) indicates that the optimal positive emotions capable to initiate and maintain the required amount of effort to perform a task towards their success. As evidenced, Pre-competition stress (PCS) was considered common stress among athletes which usually distracts athletes from their specific sports task, fails to cope with the performance during the competition (Miles et al., 2016).

A study by Freeman \& Rees (2009) suggested that among 118 high-performance male golfers proved that positive emotions such as excitement and happiness were associated with better sport performances, while negative emotions such as anger, anxiety, or shame were associated with poor sports performance. Another study by Lane et al. (2010) studied the association of emotions with optimal and dysfunctional performance among 284 volunteer students participants from various sports which includes track and field, soccer, rugby union, hockey, basketball, volleyball, cricket, netball, lacrosse, tennis, badminton, martial arts, golf, water polo, boxing, and distance running. Similar to the previous study, Lane et al. (2010) reported that positive emotions like happiness, calmness, and vigor were associated with optimal sports performance whereas negative emotions such as anger and confusion were associated with poor performance. Though these studies applied different emotional tools such as Stress Appraisal Measure (SAM), a 20-item self-reported questionnaire to report perception of support availability, emotional intelligence scale, and the 24-item Brunel Mood Scale (BRUMS) to test the participants' emotional state. However, both these studies reported positive emotions are the key factor that optimizes sports performance (Denny \& Steiner, 2009; Lane et al., 2010).

The response of 4-weeks Mindfulness Meditation Therapy (MMT) on elite shooters showed an effect on HPA-Axis by decreasing the level of salivary cortisol among experimental participants $(n=48)$ as a reliable physiological marker in PCS compared with the control group ( $\mathrm{n}=48$ ) (John et al., 2011). Another study on junior elite soccer players $(n=41)$ showed that $67 \%$ of the players in the mindfulness-based intervention remained injury-free and their attention level possibly decrease their injury risks (Ivarsson et al., 2015). The effectiveness of mindfulness was measured with the psychological instrument by using the Mindful Attention Awareness Scale (MAAS) on anxiety and sports performance training techniques among badminton players $(n=40)$. The results showed a reduction in post-test anxiety as compared to the pre-test results. Besides, the mindfulness scores among players showed improvement in their awareness and enhanced athletic performance (Moghadam et al., 2013). The authors found the impact of mindfulness influence burnout of stress level among 382 athletes towards perceived performance in their academic and sports activities in $79 \%$ of respondents. However, the participants perceived performances in sports were negatively related to their burnout level. The study suggested that mindfulness can be an important stress buffer and may help elite youth athletes to avoid burnout and perform better (Moen et al., 2015). The studies applied MAAS as the measuring tool following their mindfulness intervention (Moghadam et al., 2013; Jekauc et al., 2016).

\subsection{Sports Individuals anxiety and depression}

Mental illness greatly affects the day-to-day healthy living, which might cause serious functional impairments such as anxiety and depression that are found to be predictors of poor athletic performance. According to the American College Health 
Association (ACHA) survey, $30 \%$ of the 195,000 student-athletes have been identified as having depression over the past 12 months, and $50 \%$ reported having anxiety over the same period which might be due to pre-competition anxiety (PCA) (Davoren \& Hwang, 2014). Ferreira et al. (2007) reported that the incidence of PCA among $(n=42)$ Paralympic athletes. They studied the temporal patterning components analysis for 20 minutes, 2 hours, and 1-week among these athletes found that anxiety is a common problem, and suggested the importance of clinical intervention to deal the emotional distress, to benefit the individual against the emotional problem, and support them to cope with their stress.

Sports injuries are defined as tissue damage or physical trauma along with functional impairment (Scott-Hamilton et al., 2016). The athlete who has suffered injury is potentially at the risk of developing posttraumatic stress disorders and depression 6- times more in chances as compared to the non-injured athletes. Besides, the injured athletes also exhibit greater anxiety and lower selfesteem (O’Connell \& Manschreck, 2012). In chronic sports injuries, athletes are more likely to become depressed than their teammates. Practicing in elite-level sports offers a completely different set of circumstances for athletes that place them in a highpressure career with stressors and limitations that tend to cause injury (Schaal et al., 2011). A study among rugby players $(n=470)$, examined the role of psychological factors, their prediction, and sport-related injury prevention to assess somatic anxiety, worry, and concentration disruption. Their results showed that social support, coping skills, and previous injury closely interacted with life stress and injury (Maddison \& Prapavessis, 2005). Another study by $\mathrm{Li}$ et al. (2017) measured preseason anxiety and depression and reported a total of 597 injuries with $40.6 \%$ preseason injuries, $28.8 \%$, and $21.7 \%$ of athletes suffered from anxiety and depressive symptoms. Furthermore, athletes with preseason anxiety symptoms showed a higher injury incidence rate compared to athletes without anxiety symptoms. In general, anxiety increases fear (Scott-Hamilton et al., 2016), when this persists over a period that affects the personality of athletes as trait anxiety, whereas that affects temporary as state anxiety (Ensari et al., 2015). On the other hand, the state anxiety classified depends on the mental state and physical state as cognitive anxiety and somatic anxiety respectively (Waechter \& Stolz, 2015).

\subsection{Mindfulness in optimizing sports performance}

Elite athletes face a variety of challenges in their careers, leading to important steps to ensure that sports psychologists have an appropriate response to athletes' challenges in the field of sport (Birrer et al., 2012). Over the last 30 years, the techniques used were primarily from psychological skills training (PST) with a set of systems for self-talk, imagery, goal setting, and arousal regulation based on cognitive-behavioral theories. Recently, the rise of interest in mindfulness-based interventions has increased in sport psychology which ultimately creates an impact on optimizing sports performance (Elmagd, 2016). The 8-week mindfulness intervention among the competitive cyclist $(n=27)$ showed increased attention of the athletes, decreased sport-specific anxiety, and sport-specific pessimism compared to the control group $(n=20)$ cyclist (Scott-Hamilton et al., 2016).

Mindfulness mediation practice can reduce anxiety (Keng et al., 2011) and this practice has been reported to have associated with the ability to let go of and decreased the occurrence of negative thoughts (Evans et al., 2008). The trait mindfulness among 133 elite athletes and their levels of engagement from various sports showed that trait mindfulness encouraged a positive functioning in high demand situations, which improves athletes' performance. Besides, mindfulness was found to be able to reduce the state anxiety before a competition of the athlete (Röthlin et al., 2016). A study by Walker (2016) explored the relationship between mental toughness and mindfulness among provincial adolescent female hockey players $(\mathrm{N}=484)$, found that mindfulness exhibited positive correlations with positive emotions (Walker, 2016).

The mindfulness acceptance commitment (MAC) approach among 118 collegiate sports participants from various sports like soccer, field hockey, crew, and wrestling, exhibited a significantly greater increase in coach ratings and increase in flow experience comparing with PST participants (Gardner \& Moore, 2004; Lutkenhouse, 2007). Another study by Vøllestad et al. (2011) investigated the effect of MBSR on self-referred participants $(n=76)$ under heterogeneous anxiety disorders reported to have higher relief from depression, anxiety, and trait anxiety. Further, the study evidence that mindfulness has fully mediated a change in acute anxiety level and partial changes in trait anxiety level.

Kaufman et al. (2009) developed MSPE to track the sports performance, affected flow states, and psychological characteristics of the archers $(n=11)$ and the golfers $(n=21)$. Their results indicate that MSPE has been a positive intervention to improve sport-confidence flow, knowledge, and aspects. A further study on the long-term effects of MSPE psychological aspects of the individual athlete and their athletic performance was conducted among golfers, archers, and long-distance runners $(N=25)$ in the set duration of one-year. Their results showed the athletes manage to cope up with the depression level. Specifically, the longdistance runners showed improvement in their time duration, performance, and trait variables. The authors recommended MSPE as a promising approach for sports individuals that enhance longterm changes in trait variables towards athletic performance (Thompson et al., 2011; Kaufman et al., 2018). Another study 
among $(n=45)$ collegiate athletes who attend 75-min, 6-week MSPE reported positive psychological assistance such as mental strength and relaxation (Mistretta et al., 2017).

Mindfulness Meditation Training for Sport (MMTS) is a mindful based intervention that was introduced by Baltzell \& Akhtar (2014) with traditional psychological skills training among female collegiate athletes $(n=42)$, showed that athletes who received MMTS had increased in mindfulness score. Another study explored mindfulness intervention on women soccer players, coaching staff, and their entire team. Their result showed in the beginning participants mostly had difficulty in understanding the process of meditation, however after undergoing MMTS, they reported an increased ability to accept and experience positive emotions, both on and off their field. At the session end, the participants felt sport-focused mindfulness programs help in enhancing sports performance (Baltzell et al., 2014). Similarly, a study by Cote et al. (2019) on MMTS 2.0 among collegiate tennis players $(n=9)$ improved their sports concentration, adaptability, and tolerance level.

Table 2 Mindfulness study design, population, interventions, tools, and results

\begin{tabular}{|c|c|c|c|c|c|}
\hline $\begin{array}{l}\text { Author } \\
\text { reference }\end{array}$ & Study design & $\begin{array}{c}\text { Study } \\
\text { population }\end{array}$ & Intervention & Tools used & Results \\
\hline $\begin{array}{l}\text { Röthlin et al., } \\
2016\end{array}$ & $\begin{array}{l}\text { Cross-sectional } \\
\text { study }\end{array}$ & $\begin{array}{l}(\mathrm{N}=133) \quad \text { Elite } \\
\text { athletes }\end{array}$ & $\begin{array}{l}\text { Perception of Trait } \\
\text { mindfulness to promote } \\
\text { positive } \\
\text { performance in high } \\
\text { demanding situations in } \\
\text { sports }\end{array}$ & $\begin{array}{l}\text { 37-item Comprehensive } \\
\text { Inventory of Mindfulness } \\
\text { Experiences }\end{array}$ & $\begin{array}{l}\text { Trait mindfulness reduced } \\
\text { performance worries and } \\
\text { influencing athletes' } \\
\text { performance in their } \\
\text { specific sports }\end{array}$ \\
\hline Walker, 2016 & $\begin{array}{l}\text { Experimental } \\
\text { study }\end{array}$ & $\begin{array}{l}(\mathrm{N}=484) \\
\text { adolescent } \\
\text { female hockey } \\
\text { players }\end{array}$ & $\begin{array}{l}\text { Relationship between } \\
\text { mental toughness and } \\
\text { mindfulness }\end{array}$ & $\begin{array}{l}\text { 14-item Sports Mental } \\
\text { Toughness Questionnaire } \\
\text { 10-item Child and } \\
\text { Adolescent Mindfulness } \\
\text { Measure }\end{array}$ & 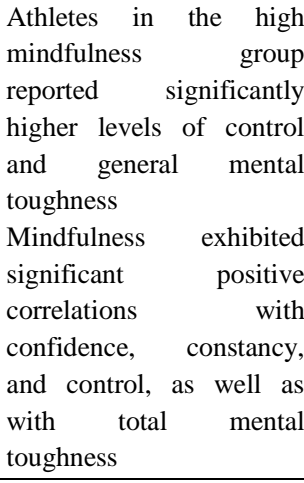 \\
\hline $\begin{array}{l}\text { De Petrillo et } \\
\text { al., , } 2009\end{array}$ & $\begin{array}{l}\text { Experimental } \\
\text { study }\end{array}$ & $\mathrm{N}=25$ Runners & $\begin{array}{l}\text { Determined the effects of } \\
\text { 4-weeks Mindful Sport } \\
\text { Performance } \\
\text { Enhancement (MSPE) }\end{array}$ & $\begin{array}{l}\text { 39-item Kentucky } \\
\text { Inventory of Mindfulness } \\
\text { Skills (KIMS) } \\
\text { 13-item Toronto } \\
\text { Mindfulness Scale (TMS). } \\
\text { Mindfulness Practice Log }\end{array}$ & $\begin{array}{lr}\text { MSPE group showed } \\
\text { significantly more } \\
\text { improvement } \\
\text { perfectionism compared } \\
\text { with controls groups }\end{array}$ \\
\hline $\begin{array}{l}\text { Kaufman et } \\
\text { al., } 2009\end{array}$ & $\begin{array}{l}\text { Experimental } \\
\text { study }\end{array}$ & $\begin{array}{l}\mathrm{N}=11 \quad \text { archers } \\
\text { and } \mathrm{N}=21 \\
\text { golfers }\end{array}$ & $\begin{array}{l}\text { 4-weeks MSPE to check } \\
\text { the performance and } \\
\text { psychological } \\
\text { characteristics } \\
\text { participants }\end{array}$ & $\begin{array}{l}\text { 39-item } \\
\text { Inventory of } \\
\text { Skills (KIMS) } \\
\text { 13-item } \\
\text { Mindfulnesy } \\
\text { Daily } \\
\begin{array}{l}\text { Practice Log } \\
\text { Toronto }\end{array}\end{array}$ & $\begin{array}{l}\text { MSPE is a promising } \\
\text { intervention to enhance } \\
\text { flow, mindfulness, and } \\
\text { aspects of sport- } \\
\text { confidence }\end{array}$ \\
\hline
\end{tabular}

Journal of Experimental Biology and Agricultural Sciences http://www.jebas.org 


\begin{tabular}{|c|c|c|c|c|c|}
\hline $\begin{array}{l}\text { Thompson } \\
\text { et al., } 2011\end{array}$ & $\begin{array}{l}\text { Longitudinal } \\
\text { study }\end{array}$ & $\begin{array}{l}\text { archers, } \\
\text { golfers, and } \\
\text { long-distance } \\
\text { runners }(N= \\
25)\end{array}$ & $\begin{array}{l}\text { One-year follow-up } \\
\text { (MSPE), a program } \\
\text { designed to improve } \\
\text { athletic performance and } \\
\text { psychological aspects of } \\
\text { the sport. }\end{array}$ & $\begin{array}{lr}\text { 39-item } & \text { Kentucky } \\
\text { Inventory } & \text { of } \\
\text { Mindfulness } & \text { Skills } \\
\text { (KIMS) } & \end{array}$ & $\begin{array}{l}\text { MSPE techniques as a } \\
\text { promising intervention } \\
\text { for long-term changes in } \\
\text { trait variables that may } \\
\text { contribute to optimal } \\
\text { athletic performance }\end{array}$ \\
\hline $\begin{array}{l}\text { Baltzell \& } \\
\text { Akhtar, } \\
2014\end{array}$ & $\begin{array}{l}\text { Experimental } \\
\text { study }\end{array}$ & $\begin{array}{l}\text { Female } \\
\text { athletes }(\mathrm{N} \\
=42) \text { soccer } \\
\text { players } \\
(\mathrm{N}=19) \text {, rowers } \\
(\mathrm{N}=23)\end{array}$ & $\begin{array}{l}\text { Examined the impact of } \\
\text { a twelve-session, } 30 \text { - } \\
\text { minute mindfulness } \\
\text { meditation training } \\
\text { session for sport } \\
\text { (MMTS) intervention }\end{array}$ & $\begin{array}{l}\text { Mindfulness Attention } \\
\text { Awareness Scale } \\
\text { (MAAS), the Positive } \\
\text { Affect Negative Affect } \\
\text { Scale (PANAS), the } \\
\text { Psychological Well- } \\
\text { Being Scale and the } \\
\text { Life Satisfaction Scale }\end{array}$ & $\begin{array}{l}\text { Paired sample t-tests } \\
\text { highlight significant } \\
\text { increases in mindfulness } \\
\text { scores for the } \\
\text { intervention group } \\
(\mathrm{p}<.01)\end{array}$ \\
\hline $\begin{array}{l}\text { Baltzell et } \\
\text { al., } 2014\end{array}$ & $\begin{array}{l}\text { Longitudinal } \\
\text { study }\end{array}$ & $\begin{array}{l}\mathrm{N}=7 \quad \text { soccer } \\
\text { players }\end{array}$ & $\begin{array}{l}\text { 6-week, } 12 \text { session } \\
\text { mindfulness meditation } \\
\text { training for sport } \\
\text { (MMTS) program }\end{array}$ & Interview & $\begin{array}{l}\text { Participants reported an } \\
\text { enhanced ability to } \\
\text { accept and experience a } \\
\text { different relationship } \\
\text { with their emotions, } \\
\text { both on and off their } \\
\text { field, during post- } \\
\text { intervention }\end{array}$ \\
\hline $\begin{array}{l}\text { Cote et al., } \\
2019\end{array}$ & $\begin{array}{l}\text { Longitudinal } \\
\text { study }\end{array}$ & $\begin{array}{l}\mathrm{N}=9 \text { Division } \mathrm{I} \\
\text { varsity tennis } \\
\text { collegiate } \\
\text { athletes }\end{array}$ & $\begin{array}{l}\text { one-hour program or in } \\
\text { two } 30 \text {-minute segments } \\
\text { for } 6 \text { days, } 6 \text { weeks } \\
\text { MMTS 2.0 program } \\
\text { addressing the psycho- } \\
\text { education, } \\
\text { practice, and guided } \\
\text { discussion }\end{array}$ & $\begin{array}{l}\text { Participants completed } \\
\text { pre-post interview on the } \\
\text { MBI }\end{array}$ & $\begin{array}{l}\text { Interviews highlights } \\
\text { MMTS } 2.0 \text { is a practical } \\
\text { and valuable } \\
\text { intervention for } \\
\text { collegiate athletes }\end{array}$ \\
\hline $\begin{array}{l}\text { Scott- } \\
\text { Hamilton et } \\
\text { al., } 2016\end{array}$ & $\begin{array}{l}\text { Experimental } \\
\text { study }\end{array}$ & $\begin{array}{l}\mathrm{N}=27 \text { cyclists } \\
\text { in the } \\
\text { mindfulness } \\
\text { intervention } \\
\text { condition, } \mathrm{N}= \\
20 \text { cyclists in } \\
\text { the control } \\
\text { condition }\end{array}$ & $\begin{array}{l}\text { 8-weeks mindfulness } \\
\text { training } \\
\text { athletes' mindfulness } \\
\text { and flow experience and } \\
\text { decreases sport-specific } \\
\text { anxiety and sport- } \\
\text { specific pessimism }\end{array}$ & $\begin{array}{l}\text { Participants completed } \\
\text { baseline and post-test } \\
\text { measures } \\
\text { mindfulness, flow, sport- } \\
\text { anxiety, and sport- } \\
\text { related pessimistic } \\
\text { attributions }\end{array}$ & $\begin{array}{l}\text { Results suggest that } \\
\text { mindfulness-based } \\
\text { interventions tailored to } \\
\text { specific athletic pursuits } \\
\text { can be effective in } \\
\text { facilitating flow } \\
\text { experiences }\end{array}$ \\
\hline $\begin{array}{l}\text { John et al., } \\
2011\end{array}$ & $\begin{array}{l}\text { Experimental } \\
\text { study }\end{array}$ & $\begin{array}{l}96 \text { male elite } \\
\text { Shooters, } \\
\text { experimental } \\
\text { and control (48 } \\
\text { in each) }\end{array}$ & $\begin{array}{l}\text { 4- weeks of MMT and } \\
\text { one week study to } \\
\text { determine the follow-up } \\
\text { effect }\end{array}$ & $\begin{array}{l}\text { Salivary Cortisol (SC), a } \\
\text { reliable } \\
\text { physiological marker of } \\
\text { HPA- axis response in } \\
\text { reducing Pre- } \\
\text { competitive stress (PCS) }\end{array}$ & $\begin{array}{l}\text { Reduction of PCS level } \\
\text { and increase in shooting } \\
\text { performance }\end{array}$ \\
\hline
\end{tabular}

\section{Conclusion}

This review on various mindfulness approaches has been proven to Further, it conveys for the sports rehabilitation specialists that be effective in managing the sports individuals' state anxiety and mindfulness practice has diverse approaches that are transfigured depression, hence be able to enhance performance in individual from cognitive-based therapy to a mindful approach, namely from sports.

\section{MBSR to MMTS.}


However, the majority of the study reported the effectiveness of mindfulness practice was assessed by using the very subjective questionnaire MAAS for testing the participants' mindfulness attention expect one study applied salivary cortisol testing. Hence, this review suggests the need for an objective assessment method to assess the impact of mindfulness intervention in sports rehabilitation.

\section{Acknowledgments}

The authors would like to convey thanks to Mr. Jim Brown Clements, English proofreader, who has proofed the content for readability.

\section{Disclosure of interest}

The authors declare that they have no competing interests.

\section{References}

Elmagd AM (2016) General psychological factors affecting physical performance and sports. International Journal of Physical Education, Sports and Health 3 (5): 255- 264

Baltzell A, Akhtar V L (2014) Mindfulness meditation training for sport (MMTS) intervention: Impact of MMTS with division I female athletes Sporda farkındalık eğitimi (SFE) çalışması: SFE'nin I. lig kadın atletlerdeki etkisi. The Journal of Happiness \& Well-Being 2(2): 160-173.

Baltzell A, Caraballo N, Chipman K, Hayden L (2014) A qualitative study of the mindfulness meditation training for sport: Division I female soccer players' experience. Journal of Clinical Sport Psychology 8(3): 221-244.

Birrer D, Röthlin P, Morgan G (2012) Mindfulness to Enhance Athletic Performance: Theoretical Considerations and Possible Impact Mechanisms. Mindfulness 3(3): 235-246.

Cote T, Baltzell A, Diehl R (2019) A Qualitative Exploration of Division I Tennis Players Completing the Mindfulness Meditation Training for Sport 2.0 Program. The Sport Psychologist 33(3) 203-212.

Davoren AK, Hwang S (2014) Depression and anxiety prevalence in student-athletes. In GT Brown (Ed.), Mind, body and sport Understanding and supporting student-athlete mental wellness. Indianapolis: National Collegiate Athletic Association, Pp.38-39.

De Petrillo LA, Kaufman KA, Glass CR, Arnkoff DB (2009) Mindfulness for Long-Distance Runners: An Open Trial Using Mindful Sport Performance Enhancement (MSPE). Journal of Clinical Sports Psychology 4: 357-376.

Journal of Experimental Biology and Agricultural Sciences http://www.jebas.org
Denny KG, Steiner H (2009) External and internal factors influencing happiness in elite collegiate athletes. Child Psychiatry and Human Development 40(1): 55-72

Ensari I, Greenlee TA, Motl RW, Petruzzello SJ (2015) Metaanalysis of acute exercise effects on state anxiety: An update of randomized controlled trials over the past 25 years. Depression and Anxiety 32(8): 624-634.

Evans S, Ferrando S, Findler M, Stowell C, Smart C, Haglin D (2008) Mindfulness-based cognitive therapy for generalized anxiety disorder. Journal of Anxiety Disorders 22(4): 716-721.

Ferreira JPL, Chatzisarantis N, Caspar PM, Campos MJ (2007) Precompetitive Anxiety and Self-Confidence in Athletes with Disability. Perceptual and Motor Skills 105(1): 339-346.

Freeman P, Rees T (2009) How Does Perceived Support Lead to Better Performance? An Examination of Potential Mechanisms. Journal of Applied Sport Psychology 21(4): 429-441.

Gardner FL, Moore ZE (2004) A mindfulness-acceptancecommitment-based approach to athletic performance enhancement: Theoretical considerations. Behavior therapy 35(4): 707-723.

Hölzel BK, Lazar SW, Gard T, Schuman-Olivier Z, Vago DR, Ott U (2011) How Does Mindfulness Meditation Work? Proposing Mechanisms of Action From a Conceptual and Neural Perspective. Perspectives on Psychological Science 6(6): 537-559.

Huang PH (2016) Teaching (About) Mindfulness: A Tale of Two Courses, Apr. 28, 2016. Available at http://papers.ssrn.com/sol3/papers.cfm?abstract_id=2771578.

Ivarsson A, Johnson U, Andersen MB, Fallby J, Altemyr M (2015) It Pays to Pay Attention: A Mindfulness-Based Program for Injury Prevention With Soccer Players. Journal of Applied Sport Psychology 27(3): 319-334.

Jekauc D, Kittler C, Schlagheck M (2016) Effectiveness of a mindfulness-based intervention for athletes. Psychology 8(1): 113.

John S, Verma SK, Khanna GL (2011) The effect of mindfulness meditation on HPA-Axis in pre-competition stress in sports performance of elite shooters. National Journal of Integrated Research in Medicine 2(3): 15-21.

Kabat-Zinn J (2009) Wherever you go, there you are: Mindfulness meditation in everyday life. Hachette Books.

Kabat-Zinn J (1990) Full Catastrophe Living: Using the Wisdom of Your Body and Mind to Face Stress, Pain, and Illness. Delta Trade Paperback/Bantam Dell. 
Kabat-Zinn J (2012) Mindfulness for beginners: Reclaiming the present moment-and your life. Sounds True. ounds True Inc; Har/Com edition.

Karageorghis C, Terry P (2010) Inside Sport Psychology. Human Kinetics Publisher. DOI: 10.5040/9781492595564.

Kaufman KA, Glass CR, Arnkoff DB (2009) Evaluation of Mindful Sport Performance Enhancement (MSPE): A New Approach to Promote Flow in Athletes. Journal of Clinical Sport Psychology 3(4): 334-356.

Kaufman KA, Glass CR, Pineau TR (2018) Mindful sport performance enhancement: Mental training for athletes and coaches. American Psychological Association.

Keng SL, Smoski MJ, Robins CJ (2011) Effects of mindfulness on psychological health: a review of empirical studies. Clinical Psychology Review 31(6): 1041-1056.

Lane AM, Devonport TJ, Soos I, Karsai I, Leibinger E, Hamar P (2010) Emotional intelligence and emotions associated with optimal and dysfunctional athletic performance. Journal of Sports Science and Medicine 9(3): 388-392.

Li H, Moreland JJ, Peek-Asa C, Yang J (2017) Preseason anxiety and depressive symptoms and prospective injury risk in collegiate athletes. The American journal of sports medicine 45(9): 21482155 .

Ludwig DS, Kabat-Zinn J (2008) Mindfullness in Medicine. Journal of the American Medical Association 300(11): 1350-1352.

Lutkenhouse JM (2007) The case of Jenny: A freshman collegiate athlete experiencing performance dysfunction. Journal of Clinical Sport Psychology 1(2): 166-180.

Maddison R, Prapavessis H (2005) A psychological approach to the prediction and prevention of athletic injury. Journal of Sport and Exercise Psychology 27(3): 289-310.

Miles AJ, Neil R, Barker J (2016) Preparing to take the field: A temporal exploration of stress, emotion, and coping in elite cricket. The Sport Psychologist 30: 101-112.

Mistretta EG, Glass CR, Spears CA, Perskaudas R, Kaufman KA, Hoyer D (2017) Collegiate athletes' expectations and experiences with mindful sport performance enhancement. Journal of Clinical Sport Psychology 11(3): 201-221.

Mize SJS (2015) A Review of Mindfulness-Based Sex Therapy Interventions for Sexual Desire and Arousal Difficulties: From Research to Practice. Current Sexual Health Reports 7(2): 89-97.
Moen F, Federici RA, Abrahamsen F (2015) Examining possible Relationships between mindfulness, stress, school- and sport performances and athlete burnout. International Journal of Coaching Science 9 (1): 3-19.

Moghadam MS, Sayadi E, Samimifar M, Moharer A (2013) Impact assessmentof mindfulness techniques education on anxiety and sports performance in Badminton players Isfahan. International Research Journal of Applied and Basic Sciences 4(5): $1170-1175$

O'Connell S, Manschreck TC (2012) Playing through the pain: Current Psychiatry 11(7): 16-20.

Pineau TR, Glass CR, Kaufman KA, Bernal DR (2014) Self-and team-efficacy beliefs of rowers and their relation to mindfulness and flow. Journal of Clinical Sport Psychology 8(2): 142-158.

Race K (2014) Mindful Parenting: Simple and Powerful Solutions for Raising Creative, Engaged, Happy Kids in Today's Hectic World. Macmillan.

Rosenkranz MA, Davidson RJ, MacCoon DG, Sheridan JF, Kalin $\mathrm{NH}$, Lutz A (2013) A comparison of mindfulness-based stress reduction and an active control in modulation of neurogenic inflammation. Brain, Behavior, and Immunity 27(1): 174-184.

Röthlin P, Birrer D, Horvath S, grosse Holtforth M (2016) Psychological skills training and a mindfulness-based intervention to enhance functional athletic performance: design of a randomized controlled trial using ambulatory assessment. BMC Psychology 4(1): 39 .

Schaal K, Tafflet M, Nassif H, Thibault V, Pichard C, Alcotte M, et al. (2011) Psychological balance in high level athletes: GenderBased differences and sport-specific patterns. PLoS ONE 6(5):e19007.

Scott-Hamilton J, Schutte NS, Brown RF (2016) Effects of a mindfulness intervention on sports-anxiety, pessimism, and flow in competitive cyclists. Applied Psychology: Health and Well-Being 8(1): 85-103.

Segal ZV, Williams JMG, Teasdale JD (2002) Mindfulness-based cognitive therapy for depression: A new approach to preventing relapse. New York: Guilford.

Thompson RW, Kaufman KA, De Petrillo LA, Glass CR, Arnkoff DB (2011) One Year Follow-Up of Mindful Sport Performance Enhancement (MSPE) with Archers, Golfers, and Runners. Journal of Clinical Sport Psychology 5(2): 99-116. 
Vøllestad J, Sivertsen B, Nielsen GH (2011) Mindfulness-based stress reduction for patients with anxiety disorders: Evaluation in a randomized controlled trial. Behaviour Research and Therapy 49(4): 281-288.

Walker S (2016) Mindfulness and mental toughness among provincial adolescent female hockey players. South African Journal of Sports Medicine 28(2): 46.

Waechter S, Stolz JA (2015) Trait anxiety, state anxiety, and attentional bias to threat: Assessing the psychometric properties of response time measures. Cognitive Therapy and Research 39(4): $441-458$.

Weinberg RS, Gould D (2011) Foundations of sport and exercise psychology. (5th ed.). Champaign, IL: Human Kinetics.

Yeh L (2016) The effect of stress coping techniques in sports. CMC Senior Theses. Paper 1240. http://scholarship.claremont.edu/cmc_theses/1240. 